\title{
Labour Appropriation in Buhera District, South-Eastern Zimbabwe 1890-1930: the Accidental Proletarianization of an African Peasantry by a Foreign Capitalist Oligarchic Enterprise.
}

By

Davidson Mabweazara Mugodzwa ${ }^{1}$.

\begin{abstract}
.
This presentation seeks to argue that before colonial rule, the African peasant population in Buhera District [formerly called Charter District] was producing only at subsistence level: they did not seek employment outside their villages because they pursued a communal system of production which was both economically self-sufficient and selfsustaining. Colonial records show that this African peasant population of Charter stood at thirty-two thousand people even as early as 1880s. [N9/1/5, NC Charter to CNC Salisbury, 31 March 1899]. The argument of this research is that such a large human population would need a consistent and reliable supply of staple grain and other traditional foods for its daily needs. Therefore pre-colonial Charter peasantry communities pursued a successful communal mode of production which largely depended on the availability of abundant, fertile and well-watered agricultural land: accompanied by huge supply of willing organized labour which was largely provided by men, women and children. Our argument stems from the fact that during this pre-colonial era, land was neither bought nor sold but belonged to the whole community under the collective management and administration of chiefs and their subordinates who distributed land to all able-bodied adult males in the community who needed such land.

This research will largely be based on primary evidence, that is, oral traditions and colonial documents but secondary published and unpublished supplementary sources will also be consulted in our endeavour to shade light on the area under research.
\end{abstract}

Key Words: appropriation, proletariat, agriculture, land, colonial enterprise

\section{Introduction.}

Buhera District generally comprised the whole area stretching between the Save in the north and the Nyazvidzi River in the south and bordering the Salisbury-Bulawayo Road in the west near Enkeldoorn. [N9/1/5, NC Charter to 
CNC Salisbury, 31 March 1899]. The indigenous people were mainly composed of the Hera, Njanja, Rozvi and Dziva. The most important chieftainships were Gambiza, Nyashanu, Mutekedza, Nerutenga, Chitsunge, Ranga, Mombeyarara and Hokonya. [N9/1/6, NC Charter to CNC Salisbury, 31 March, 1899]. The estimated population of Charter District in 1899 was 38000 people but Beach [1990:33] has warned about the inaccuracy of colonial population figures. Therefore it is possible that this population statistic was an obvious undercount. Beach says,

"...the bigger the District the more difficult the NCs found it to count the population..." [ibid]

Charter District also ran as far west as the parallel Mwenezi and Mashava Ranges and in fact, the Ngezi Reserve tended to be handed back and forth from Charter to Hartley, neither NC really wanting it! [NSKI/1/1, NC Charter to CNC Salisbury, 31 March 1899].

Documentary evidence suggests that the indigenous people in pre-colonial Charter were basically agriculturalists and agriculture was the most important economic activity before colonial rule. [NSKI/1/1, NC Charter to CNC Salisbury, 4 April 1899]. However, there were also other economic activities such as gathering, hunting, fishing, manufacturing [making bark clothes, bark blankets, leather clothes and blankets, fish and game nets, ropes, baskets, pottery etc.], building [cattle pens, huts, fencing homesteads and fields], iron smelting, salt processing and trade [both local and international trade with Portuguese East Africa]. [ibid] Native Commissioner Reports indicate that the Shona agricultural system in Charter was clearly successful except in the southern low veld were the major constraint was periodic droughts. [N3/1/5, NC Charter to CNC Salisbury, 5 December 1899].

Jamu has estimated that by 1900, peasants in Charter District owned 2394 herd of cattle. [Jamu, 1987]. This fact alone demonstrates that pre-colonial African communities in this district were relatively rich since cattle were regarded as storage of wealth in most pre-colonial societies. Indigenous peoples of Charter District were thus primarily agriculturalists and cattle keepers and thus agriculture was the most important economic activity before colonial rule. [NSKI/1/, NC Charter to CNC Salisbury, 31 May 1899].

Schmidt [1992:1] has noted that historical researches in Zimbabwe have failed to acknowledge the crucial role played by women in production and hence they ignored gender issues which are regarded as fundamental in studying social relations of production. This paper will adopt Schmidt's approach and attempt to trace the role of women in agricultural production. We will also investigate the role of child labour in economic production and evaluate whether it was indeed child abuse or some form of apprenticeship training as there were no schools in the western sense in pre-colonial Charter. In fact this paper will show that 
documentary evidence points out that young male children from the age of twelve upwards were recruited for labour on European farms and mines!

This paper will largely investigate the effect of large scale labour recruitment on the agricultural productive sector which included animal husbandry. It is this peasant agriculture and livestock farming which supported the early colonial economic sector. We are thus going to argue that peasant production in Charter District initially sustained the colonial capitalist system which was not selfsufficient in the early stages of operation. We will demonstrate that in the early years of colonial rule, capitalist sectors of production were completely dependent on peasant produce for survival because Europeans lacked both financial capital and labour and technological know-how of farming in Africa. This dependency was however deliberately eroded by colonial legislature which now supported the emergence of European commercial agriculture and cattle ranching and thus absorbed the market once exploited by peasant production.

Our argument is that the later growth of European commercial agriculture and ranching severely shattered peasant production and set forth the gradual underdevelopment of the peasant sector. This was further complemented by other colonial measures such as labour and land appropriation and taxation.

\section{Labour shortage: the dilemma of early colonial capitalist enterprises.}

We seek to investigate the effects of labour appropriation on peasant production in the Charter District.

Mackenzie produced an interesting article entitled, 'African labour in the Chartered Company period'. [Mackenzie,1970]. Van Onselen [1976] and Phimister [1988] however have also contributed many works on the issues of labour in Southern Rhodesia. Mackenzie has argued that throughout the colonial era, the myth of shortage of African labour was a popular subject. Colonial officials and settlers argued very strongly that the,

"...development of Southern Rhodesia was being retarded by the reluctance of the African population to go to work". [Mackenzie, 1970:43].

In response to this problem several mechanisms were attempted in order to settle the problem of labour shortage. The BSAC initially attempted to boost the population of Africans in Rhodesia by inviting foreign Africans from South Africa to come and settle in Rhodesia. [ibid] The Fingos were thus identified for this promotional immigration into Rhodesia. Mackenzie also argues that other African groups were invited from the Portuguese territory, from the Northern Transvaal and from Bechuanaland as well.Some of these arrangements were said to have been secretly made. [ibid] The Chamber of Commerce of Rhodesia is also said to have encouraged immigrant labourers from Northern Rhodesia and 
Nyasaland to bring their wives and children so as to settle permanently in Rhodesia. [ibid]

Thee BSAC is also said to have taken advantage of a rising in the Barwe District of Portuguese East Africa by inviting thousands of Africans fleeing from the war in that country to settle in the Nyanga District of Rhodesia. [ibid] The male refugees were quickly recruited as labourers and their families were provided with grain and food. [ibid]

Mackenzie [1970:44] has traced the activities of the BSAC to solve the labour problem by recruiting Somalis, Ethiopians, South Arabians and Yemenis into Southern Rhodesia. [ibid] All these attempts to have foreigners to settle in Southern Rhodesia to act as labour reserves proved a complete failure for a variety of reasons. Mackenzie has shown that the Mozambican refugees packed up their belongings and left for the Portuguese territory when conditions in Southern Rhodesia did not prove favourable to them. [ibid] Mackenzie says, the imposition of taxation and rental charges angered the refugees. The Somalis and South Arabians who arrived in Rhodesia in 1900 and 1901 proved unsuitable for mine labour, in fact one group rioted in Beira and the whole exercise was scrapped. [ibid]

As a result of this labour shortage some Europeans were employing Africans from Nyasaland [now Malawi] recruited by Recruiting Agents operating there. NC Posselt observed that,

"...the Nyasa labourers with the exception of a few are giving satisfaction, the employers experience some difficulty with their language otherwise the relations between master and servant are satisfactory..." [N9/1/12, Annual Report, 31 December 1909]

We must point out that, despite the influx of African labourers from Nyasaland the labour shortage still remained unsolved. Even NC Posselt noted that, “...local employers were very short of labour...the farmers I fear will suffer much for want of labour, they cannot compete against mines in offering high wages. The higher wages and more attractive conditions prevailing at the mines will draw $97 \%$ of the labour..." [We will show that these claims of high wages and attractive conditions of work were merely lies and fabrications by the NC Charter to his superior, CNC Mashonaland for reasons unknown by this owner] By 1911, labour shortages on farms had become so acute that some farmers were deciding to turn their farms into ranches which would not demand much labour. On this matter, NC Posselt reported that, "...the usual shortage amongst farmers was again experienced. Some of the leading local farmers contemplate the discontinuance of agriculture and confine themselves to livestock keeping..." [N9/1/14, Annual Report, 31 December 1911] 
We have to state that even migrant labourers from the Cape in South Africa did not prove useful because of the poor working conditions on the farms in Charter where the workers were subjected to long working hours and grossly underpaid. Furthermore workers were fed on poor diet and housing conditions were not inviting. [N9/1/16, Annual Report 31 December 1913] In 1913, the labour situation had not even improved as shown by Posselt's report,

“... being essentially a farming district the settlers were severely handicapped and many a homestead has been minus a single servant for many months at a stretch...some farmers obtained labour in the Cape Colony but the boys did not prove satisfactory." [ibid]

In fact, farm labour in Charter was so short that some European farm-owners engaged European farm labourers at higher wage rates. [N9/1/22, Annual Report, 31 December 1919] In 1919, NC Posselt observed that,

"...locally there was a constant demand for labour and during the wheat reaping period farmers offered from $2 /$ to $4 /$ per diem but were unable to secure full requirements. In some cases they were compelled to engage Europeans labour at 10/per diem" [N9/1/22, Annual Report, 31 December 1919]

\section{Peasant response to labour recruitment in Charter District.}

This paper now wishes to trace the nature of labour recruitment as it pertained to Charter District. We seek to find out the attitude and response of peasants in Charter to labour recruitment for mines and farms. Pertinent to this investigation is our view that, in fact there was no labour shortage in Charter at all: but rather the colonial capitalist enterprises were financially handicapped to enable them to pay adequately and fairly for African labour.African peasants in this region were in fact producing surplus grain for sale at a profit and did not need to work for Europeans to accrue cash!

Both NC Taylor and his successor NC Posselt noted the reluctance of Shona peasants in Charter to register for labour. Instead, this supply was usually met by Shangani and peoples from the Portuguese territory. [NSKI/1/1, Monthly Report, 31 March 1899] Both Taylor and Posselt completely missed the point when they interestingly attributed the lack of interest to work amongst the Shona as due to sheer laziness. Even as late as 1914, Shona peasants in Charter did not show any slight indication in favour of working for the European capitalist enterprise. NC Posselt reported that,

"...although a substantial increase in the number who want to work can be shown over last year there is no doubt that a general reluctance exists among natives to go and work at all..." [N9/1/17, Annual Report, 31 December 1914] The reason for this according to NC Posselt was that the Africans in Charter were used to easy life at their respective villages. He argued that, 
“...many reasons may be assigned for this, the principal is probably the easy and happy go lucky existence they lead at the kraal. Their necessaries are easily obtained by the sale of stock..." [ibid]

In Charter the reasons why the peasants did not wish to work for the Europeans were many as indicated by NC Posselt. Basically most of the reasons were economic rather than sheer laziness as argued by most Native Commissioners in Mashonaland. NC Posselt observed that the needs for the Shona peasants were few. NC Posselt gave an interesting opinion on labour shortage and the reasons for it in his annual report of 1903 which is worth noting. Firstly he stated that there was indeed enough labour from local Africans to supply allRhodesian labour demands. NC Posselt was referring to the labour problem in general for the whole country. He wrote that,

"...firstly I consider there is numerically sufficient labour in Rhodesia to supply Rhodesian wants even with increased development of mines...”[N9/1/7-8, Annual Report, 31 March 1903]

NC Posselt characterized this labour as being of an 'inferior' quality only suitable for surface mine work. His second opinion was that,

"... as long as the natives have no pressure they will not and need not work..." [ibid]

NC Posselt attributed this reason to economic factors such as the possession of, "...unfortunately unlimited ground for cultivation, unlimited food supplies..." [ibid]

Europeans were thus generally angered that Africans had adequate food and farm lands which enabled them to pursue a semi-luxurious peasant existence which was both self-sufficient and self-sustaining. Our argument from the outset is that European enterprises were not sufficiently endowed with financial capital to pay fair and attractive wages: hence African peasants remained aloof and unwilling to offer hard manual labour for peanuts!

NC Posselt's general analysisfor the reasons why the Shona peasants in Rhodesia did not register for labour is partially correct for Charter especially for the early period of BSAC rule. NC Posselt also argued that the needs of the Charter peasants could easily be met by other means and not necessarily through selling labour to the European capitalists. He arrogantly observed that, “...a few goat skins will provide them [i.e. peasants] with wearing apparel for years, all other clothing required can be obtained from traders at the cost of a few buckets of grain. Their total wants then account to ten shillings per annum to pay the government tax and an additional or double that amount on private lands [i.e. African peasants living on their land but which was now appropriated by Europeans had to pay rent]...." [N9/1/8, Annual Report, 31 March 1903]

NC Posselt noted that since the wants of Shona peasants in Charter were very few and could easily be met by selling of grain to European traders then there 
was no incentive for them to register for mine labour. Posselt then made several recommendations to curtail this seemingly Shona laziness, "... what then can be an inducement to make a native work? Create for him as many wants as possible and induce him to adopt more modern methods of cultivation and tear him away from his beer pots..." [ibid]

NC Posselt thus advocated for colonial legislation to be passed to curtail the peasants' habits of beer drinking during the agricultural off-season and also to enforce them to seek employment on European farms and mines. Of cause in this regard he totally missed the point again! Forced labour would not solve the problem of labour shortage because of the inherent contradictions which go with it which overally renders it unproductive. Moreover, if peasants were forced to 'adopt modern methods' of farming this would necessarily raise production to higher levels than the previous level. If this occurred the peasants would then not find it necessary to register for labour.

As already highlighted above, the peasants in Charter still refused to register for labour on European enterprises because of prevailing positive and negative economic circumstances at that time. Basically we can state that since peasants possessed productive agricultural land they increased production so as to meet the government tax obligations. Furthermore, even though a large number of peasants in Charter continued to live on alienated land [i.e. land which traditionally belonged to them] they however continued to produce surplus grain on a large scale and this surplus was still disposable at the local trading stations which had mushroomed all over the district.

Peasants obtained adequate cash from selling their grain and livestock to European traders. As early as 1898, NC Taylor reported about this ability of peasant producers in Charter to meet the demands of grain from as far as Chaka in Chirumanzu, Hartley mines, Matabeleland mines, Globe and Phoenix mine in Kwekwe. In fact Charter District had supplied most of the grain needed in the country in 1895 to 1896 because the rest of the country was in turmoil and no agricultural production was taking place because of war. [N9/1/4, Annual Report, 31 March 1898] Thus NC Posselt was correct to report that as long as peasants possessed adequate productive land they would not register for labour on European holdings.

Arrighi [1973:185] has argued that in Southern Rhodesia, the establishment and expansion of the mining sector without an accompanying capitalist agricultural industry initially created favourable market opportunities for the development of an African peasantry in significant numbers. In Charter Arrighi's thesis is clearly supported by available evidence. Africans in the district preferred an agricultural economy to any other and as both NCs Posselt and Taylor have observed, the Shona of Charter had little enthusiasm for working for the whites, whether it was at mines or farms. 
We have to state that during the early period of colonialism, farming was more profitable than deriving income from mine or farm labour. It has already been established above that in Charter during the early period of colonialism, farming was more profitable than deriving income from the mine or farm labour. In Charter, peasants who owned a plough and a span of trained oxen or donkeys, not only survived but produced surplus for sale to European traders. On this note NC Posselt reported that, "...a large number of natives are sufficiently wealthy in stock to meet all their requirements and with the advance in agriculture and demand for their products, natives find they can better their position by giving more attention to these than by going to work... [for Europeans] “

Thus if peasants could accrue profit by growing grain on a large scale they found no incentive for working for Europeans. As noted by Phimister the development of the mining industry in Southern Rhodesia created a demand for grain. [Phimister, 1977:258]. This demand for grain was also felt in, Charter District and NC Taylor observed this trend where peasants increased production in order to sell grain to the mines. [NSKI/1/1, Monthly Report, 31 May 1899] In connection with this increased demand for, Phimister has argued that, "...the scattered extent of the Southern Rhodesian mining industry provided the African peasantry with widespread markets for its produce...such markets although of differing size and duration expanded constantly as more mines were actively developed and brought into production. The proliferation of small workings after the beginning made to the restructuring of the mining industry in 1903 greatly increased the number of markets likely to depend on peasant produce." [Phimister, 1977:258].

As a result of such markets, Charter peasants were reluctant to register for labour. The peasants in Charter District showed no enthusiasm especially for mine labour. In his report, the NC noted that, "...even though there was a great demand for labour in Matabeleland only a batch of Nyembans from Portuguese territory on the East Coast applied to me for mine labour..." [NSKI/1/1, Monthly Report, 31 March 1899]

We have to point out that mine labour was hated because it was laborious and the monthly rate of payment was clearly meagre. Apart from this the peasants did not wish to be separated from their families by virtue of becoming migrant labourers. The peasants were only too aware of the social consequences of leaving their wives and homesteads. Colonial enterprises only targeted male adults for mine and farm labour, thus discriminated against women. Men who went to work for long periods at the mines did not take their wives with them during this long period. Women were not also allowed at the mining residential compounds. We must assert that wages paid for both mine and farm work were too low to tempt anyone to register for such work for three months. In 1899 mine workers 
were earning between 30/ to 40/ monthly while those who had acquired some experience in Kimberley and Johannesburg mines in South Africa were paid from $60 /$ to $70 /$ a month.It is thus clear that the monthly wage obtained for mine labour was pitifully low and peasants could easily sell off three bags of grain to raise such an amount earned from the whole month's hard labour on the mines! It is thus understandable why mine labour was not attractive to peasants in Charter.

At the same time we can argue that, while it was true that in areas distant from European markets, cash obligations could only be met through wage employment, in Charter European traders were actually buying grain for re-sale to these mines in Mvuma, Hartley, Beatrice, Kwekwe and Matabeleland.A network or transport system was already established and it facilitated the ferrying of grain from the centre of production to areas of demand. Some enterprising African peasants owned carts and trolleys which enabled them to take advantage of the transport business and they carried grain to such centres also and thus competed with European traders! In 1910, African businessmen owned only two wagons. [N9/1/12, Annual Report, 31 December 1910] By 1914, African traders owned nine wagons and one trolley and these had increased to eighteen wagons and seven trolleys by 1920. [N9/1/23, Annual Report, 31 December 1920]

\section{Proletarianization of the African peasantry in Charter District: the 'accidental' creation of a vibrant and wealthy competitive peasant class.}

This paper wishes to argue that African peasants now produced for an extended market stretching hundreds of kilometres away: it was not the intention of the colonial economic system to create such a vibrant and wealthy peasant class.NC Reports reveal evidence towards peasant prosperity during the said period. In 1911, NC Posselt reported that,

"...most of the natives may be regarded as in a state of affluence, they realise good prices for their cattle..." [N9/1/22, Annual Report, 31 December 1911]

To reinforce the argument about the newly acquired status of the former peasants, NC Posselt wrote that,

"...others are well-off in stock and realize good prices...to put the position in a nutshell the native formerly commoners are in a state of affluence and their prosperity is rapidly growing. From this it may be safely argued the labour supply of the future will generally diminish..." [N9/1/15, Annual Report, 31 December 1912]

From the NC's reports, it would appear that European farm owners were in a desperate position as far as labour shortage was concerned. This labour shortage prevailed all the way up to the early 1930s. This era coincided with the period of 
peasant prosperity in Charter. The peasant production had developed tremendously during the period 1894 to the 1930s.

Agricultural and livestock production was no longer for subsistence but was now geared to satisfy the profit motive.Africans began to pursue an affluent existence as they now produced surplus for sale which allowed them to accrue monetary benefits from agricultural and livestock production. They acquired new tastes for European clothes, food, European made wagons, trolleys, ploughs and other western paraphernalia which enhanced life's comforts. Some enterprising African entrepreneurs competed on the same level with European traders and travelled hundreds of kilometres to sell grain and in return they bought European manufactured goods for the domestic market at their respective villages where they opened up trading shops. Indeed a new class of wealthy peasants emerged in Charter. These wealthy traders opened up shops all over the Charter hinterland and began to buy grain and sell European manufactured goods and they no longer worked on their farms but employed farm labourers who were paid better wages than what European enterprises. They became employers of African labour just as Europeans could also employ peasants! [Interview with Kushingaira Mutekedza, 71 years old, female member of the Mutekedza chiefly family, Mutekedza area, 21-02-13]

There are many reasons why peasants detested working on European enterprises. European enterprises demanded contracts of three months or more, the African labourers were not allowed to leave the farm or mine compound until the three months had expired. [Interview with Tandari Pfunye, 89 years old, peasant farmer, Handikori Village, 26-02-13] Above this the diet provided by the mine owners was so poor as compared to what the peasant would have in his own home. [Interview with Mujakari Pfunye, 90 years old, peasant farmer, Handikori Village, 26-02-13] Living quarters were also terribly appalling and that there was not enough money earned to sustain the worker himself, let alone a family. [Interview with Kufahakurambwi Chawatama, 72 years old, peasant farmer, Mombeyarara Village, 24-02-13]

At this stage we need to point out that even the peasants who indeed registered for mine work resisted every effort to pay tax. NC Posselt complained that those employed on mines and farms were reneging in paying tax and that they were always in arrears. In 1919, NC Posselt reported that,

"...there is no doubt that natives are more and more disinclined to go out to work and at present there are no real inducements for them to do so... they argue that the wages are no better than before whilst all commodities have risen enormously in price and the majority of cases far beyond their powers of purchase..."

It must be realized however, that peasant production in Charter continued to rise because land was still fertile due to the traditional practice of shifting cultivation. 
There was adequate virgin land to permit peasants to leave some farmland farrow while virgin land was prepared. We have already asserted thatcolonial occupation of Southern Rhodesia was not followed by shortage of land on the part of the colonized. The reason was that even though Europeans pegged off large stretches of traditional African farmlands this was not followed by physical occupation of the farms. Africans continued to live on farms already appropriated by Europeans and some peasants were not even aware that their ancestral lands had been appropriated until later when the new owners began to levy tax on the peasant tenants.

Phimister [1988:22] has shown that in 1899 the Anglo-Boer War prevented Europeans from importing their food requirements from the Afrikaner Republics and British colonies to the South. Thus, as a result of the cutting off of these vital supplies, the bulk of the fresh produce and grain needs of the South Rhodesian mines including beef and beer were supplied by local African peasantries. [ibid] Phimister argues that peasants had a virtual monopoly for supplying these agricultural products and they obtained relatively high prices for their produce.

We have also established that Europeans farm owners did not have adequate financial resources to start commercial farming on a large scale during this early period before 1904. As a result, they preferred to derive income from the quit rent charged on peasant tenants. This paper also demonstrated that African peasants developed the financial capacity to easily pay off their rental obligations from the proceeds obtainable after grain sales: this marked the development of the proletarianization of the peasantry.

Phimister [ibid] has noted that, "...even Cecil John Rhodes [the father of British imperialism in Southern Africa] was startled by the extensive acreage cultivated by Africans. When confronted with a report which claimed that the estimated African population of 500000 worked over 600000 acres Rhodes could hardly believe this possible..."

Schmidt [1992:43] has advanced the argument that in Mashonaland most agricultural production was performed by women. In Charter District this view does not find much supportive evidence. Even though both the Hera and Nyanja were well-known for being polygamous we have no evidence that this was a deliberate attempt to create a labour reserve by accumulation of wives.

Schmidt has postulated that,

"...the opening of new markets and the imposition of taxes following European occupation served as an impetus to increased peasantization [or proletarianization, because now peasants worked full-time selling their labour power for the increased production of agricultural production and livestock farming] and the burden of augmented agricultural labour fell heavily on women's shoulders". [ibid] 
This paper argues that in Charter, Shona men did not abandon agricultural work to women. [Interview with Machemera Muzari, 56 years old, female peasant farmer, Handikori Village, 19-02-2013] Men took a central part in agricultural tasks such as ploughing, weeding, harvesting and thrashing grain and packing it in matura [granaries] spanning cattle and donkeys, training draught animals and herding cattle, building houses and thatching them. [Interview with Chengeto Pfunye, 66 years old, female peasant farmer, Handikori Village, 26-02-13] Women also did the same tasks. [ibid]

NC Posselt complained that, Shona women were not so industrious, "...it is noticeable that many women are showing increasing tendency of independence and reluctance to do their share in the land expecting their husbands to employ labour...." [N9/1/26, Annual Report, 31 December 1923] This view shows two issues at stake in Charter: that firstly women benefited economically from the proceeds from agricultural production and had rights and secondly that some wealthy peasants were in powerful financial positions to actually employ other Africans from the same area! These prevailing situations indicate that in Charter District, peasants were elevated to the status of proletariats because they now totally depended on the sale of their labour power in return for monetary payment. In the Charter District, the case of exploitation of man by man became the order of the day as the African population increased production to accrue material wealth from agricultural production.

With regards to labour, it must be noted that the bulk of work in the fields was performed by hordes of both men and women during nhimbe, which was a communal labour practice. Mtetwa [1976:234] has described nhimbe in some detail, when he says,

“...the Duma, like the other Shona evolved a labour supply system or a form of cooperation whereby neighbours, mutually helped one another in the fields, clearing the fields, planting, weeding, harvesting, threshing and doing various other tasks such as building granaries, huts, cattle pens, fencing fields with thorn bushes and serving of beer, sadza [a staple main dish of most Shona] and meat always followed after work. They pooled together all the available resources, implements and manpower of the neighbours..."

The person calling the nhimbewould provide food and beer for the work party at no cost. [N9/1/12, Annual Report, 31 December 1909] Each family or household would always get a chance to hold the nhimbeto perform activities described above. On each of these occasions both male and female members of the village performed the task of the day to the usual accompaniment of beer, song and dance: but all the same the work was always accomplished in an orderly manner! However, the number of male and female participants would always vary because a household had the option of sending a male or female participant to the nhimbe. As a result, some of these nhimbecould be over-represented by 
men or sometimes by women depending on the nature of the task to be performed. [Interview with Chipiwa Gwatidzo, female peasant farmer, Chawatama Village, 24-02-13] At the nhimbe, the host was expected to feed his guests lavishly to make himself/herself popular and also in order to elicit for their maximum support in performing the task at hand. On this note, NC Posselt observed in 1923 that,

"...there is naturally an extravagance with grain and large quantity of beer brewed in connection with their agricultural operations. In the past this averaged 10 to 20 large pots [magate] for a particular piece of work, now it is common thing to see as many as 50 to 60 large pots at a time..." [N9/1/26, Annual Report, 31 December 1923]

Thus in Charter like elsewhere in Mashonaland nhimbe was a popular method by which peasants executed productive work on their fields. It involved large numbers of peasants who functioned in an organized fashion, taking breaks during the day to consume the popular mamba [African brewed beer], but all the same having the job at hand done. It is to a large extent this communal labour practice which accounted for the rise of peasant production in Charter and as a result peasants did not wish to register for labour. Furthermore, we may state that it is this increased and purposeful production which now elevated peasants to the level of proletariats: their labour power was now quantifiable and profitable on the newly established colonial capitalist economy.Labour was now a commodity: it was available for sale!

NC Posselt for example wrote with exaggerated contempt that, "...with the exception of natives such as the messengers, native police and a few chiefs who employ herdboys and general servants, natives are not employers of others. As is well-known their method of assisting one another in the fields is by the agency of beer..." [ibid]

We must assert that NC Posselt missed the point altogether on two levels:firstly these communal work parties were a force to reckon with in agricultural production and wealthy peasants who provided large quantities of both beef and beef benefited tremendously from such labour which was needed in their large fields. Secondly, there were many wealthy peasants [hurudza], traders and merchants and other entrepreneurs who employed other Africans all over Charter District.

We wish to state categorically that peasants in Charter also resisted labour recruitment because Europeans especially those of Dutch origin who operated from the Enkeldorn area brutally treated African workers. Documentary evidence is abundantly available and supports this alleged brutality. The ill-treatment of adult male Africans was not limited to Enkeldorn only, but to many other Districts in Rhodesia. NC Taylor was having problems in persuading Africans to 
work for Europeans in the Charter District because of alleged brutality of European masters in that area. Taylor reported in 1899 that,

"...I have great difficulty to get natives to work for the Dutch farmers owing to ill-treatment by some and withholding of their wages..." [NSKI/1/1, Monthly Report, 30 June 1899]

In fact NC Taylor wrote several circulars to these European farmers to stop these acts of brutality. For example on 14 May 1899, NC Taylor wrote to Van der Merwe of Enkeldorn that,

“...the three boys who were working with you have come to complain that you have not paid them for two months that they worked on the grounds that they killed your fowls. This they deny saying that jackals killed the fowls, you have no rights to keep all the money back..." [NSKI/1/1, NC Charter to J. W. Van der Merwe, 14 May 1899]

It seems that this trend was widespread amongst Dutch farmers. On 22 May 1899, NC Taylor wrote to another Lamprecht, complaining of a similar problem, "...two boys [these are adult males] Mangambi and Gweneze that were registered with you on 22 February for three months came in to complain that their time was up and that you refused to pay them. Will you kindly pay their 1.15 pounds due to each of them..." [NSKI/1/1, NC Charter to C. Lamprecht Esq, 24 May 1894]

Cases of flagrant flogging and ill-treatment of Africans are also documented. On 3 June 1899 the NC Charter wrote to the manager of Beatrice Mine in Umfuli to complain about alleged brutality against African workers. He wrote,

"...the two bearers of this have come to complain that you set dogs on them and beat them. One has a mark on his head where he was struck. I must warn you that this sort of thing cannot be allowed..." [NSKI/1/1, NC Charter to Richardson, Beatrice Mine, Umfuli, 3 June 1899]

On a similar note the NC Charter wrote to L.G. Hoffman that, "...these two boys have come to me to complain that they have worked two months without getting any pay and that you kicked them and hit them for nothing. I must request that you pay these boys for their work..." [NSKI/1/1, NC Charter to L.G. Hoffman, 15 June 1899]

There are many other such cases where European employers ill-treated African workers in order to cause them to run away from their work places so as to withhold their wages. For example, on 9 May 1899, the NC Charter wrote to the NC Hartley that,

"...the bearer has come to complain that his master thrashed him with a whip [sjambok] he showed me the marks. Will you kindly inquire into this..." [NSKI/1/1, NC Charter to Hartley, 9 May 1899]

Mine owners in Hartley and Umfuli seem to have been notorious for hitting the mine labourers with sjamboks. Sjamboks were thick leather whips made from the 
hides of wild animals such as hippopotamus. [Interview with Makotore Pfunye, 66 years old, peasant farmer who formerly worked at a European farm, Handikori Village, 22-02-13] Despite several warnings from the NC Charter, this trend of deliberately withholding wages and brutality did not stop. For example, L.G. Hoffman continued to ill-treat workers until the NC refused to supply him with any labour whatsoever. [NSKI/1/1, NC Charter to L.G. Hoffman, 15 June 1899] On 18 June 1899 the NC Charter wrote to Hoffman again to state that, "...these boys have come to complain that you flogged them for refusing to kill your dog, they say they were afraid to do for fear that you could make them pay for the dog, I must inform you that if you beat boys again in this way, you will have great difficulty in getting boys as they will object to work for you and I certainly won't send them there where they are not properly treated...they also say that although they have worked for two months they have not yet received their pay..." [NSKI/1/1, NC Charter to Hoffman, 18 June 1899]

By 30 June 1899 NC Taylor was urging the CNC to implement legislation to deal with Europeans who ill-treated their employees. He condemned the ineffectiveness of the Masters and Servants Act in such situations. It would thus appear from the NC's reports that these cases of ill-treatment were genuine and the practice of withholding wages proved detrimental to the NC's efforts to recruit labour for such employers.

\section{Conclusion.}

This presentation has attempted to show that the colonial capitalist economy operating in Buhera District from 1890 to 1930 accidentally created an African proletariat which consciously sold labour power for monetary benefit and was unwilling to work for anything less!

The reason was that early European Commercial Agriculture in Buhera failed to take-off because of financial limitations despite the possession of large tracts of land which had been appropriated from the same peasant population. As a result European economic survival largely depended on peasant agricultural production and labour. Peasants responded by increasing agricultural production. The paper attempted to show that peasants went through a period of rapid prosperity courtesy of accidental colonial policy failure by the capitalist Rhodesian whites. Some prosperous peasants [and there were many thousands of these hurudza] were already owners of sophisticated means of production such as steel ploughs, draught animals including oxen and donkeys, scotchcarts, wagons, trolleys and trading shops: they utilized the newly acquired means of production effectively to increase economic production on an even larger scale. These hurudza[wealthy peasants] even ventured into the transport business where their services were regularly in demand as they were hired by both European and African clients! 
Some innovative peasants even designed and manufactured their own scotchcarts, copying the European model, without license of course! These peasant entrepreneurs manufactured these wagons on a large scale and sold to an expanding African market. Peasants also owned homemade sleighs [chireyi] and these were used extensively throughout Buhera to transport grain to the areas of demand.

This presentation also chronicled the peasant response to colonial labour recruitment and concluded that African people in Buhera detested working in mines and farms owned by Europeans for a number of reasons which were basically economic. European capitalist enterprises paid meagre wages for both mine and farm work and peasants had no time for such economic abuse! Furthermore, we asserted that both mine and farm labour were laborious and the working conditions and housing arrangements were not at all attractive. We demonstrated that Europeans, especially those of Dutch origin brutalized and illtreated African workers who now refused to work for them anymore.

\section{References}

A. Secondary sources: Books and articles.

Arrighi G and Saul, Essays on the political economy of Africa, Monthly Review, London, 1973.

Beach D.N, "Afrikaner and Shona settlement in the Enkeldoorn area, 1890-1900", in Zambezia, $1970,1$.

Beach D.N, "The Shona economy: branches of production", in R. Palmer and N. Parsons, [eds], The roots of rural poverty in Central and Southern Africa, Heinemann, London, 1977.

Beach D.N, War and politics in Zimbabwe, 1840-1900, Mambo Press, 1986. Beach D.N, A Zimbabwean Past, Mambo Press, 1994.

Beach D.N, The Shona and their neighbours, Blackwell, Oxford, 1994.

Beach D.N, "Second thoughts on the Shona economy: suggestions for further research", Rhodesian History, 1976, 7.

Blake R, The history of Rhodesia, Eyre Methuen, London, 1977.

Illife J, Famine in Zimbabwe, Mambo Press, Gweru 1990.

10. Mackenzie J.M, “A pre-colonial industry, the Njanja and the iron trade”, in NADA, 1975, 11.

Mudenge S.G, A Political history of Munhu Mutapa, 1400-1902, Zimbabwe Publishing House, Harare, 1988.

Mtetwa R.M.G, "Red soils in Mashonaland", in Rhodesian History, 1975, 6.

Rodney W, How Europe underdeveloped Africa, Zimbabwe Publishing House, 1980.

Marx K, Critique of political economy, Foreign Languages Publishing House, Peking, 1976.

Marx K, On colonialism and mordenization, Double Day Anchor, New York, 1969.

\section{B. Theses and dissertations.}

Jamu T.T, “The growth and control of African cattle herds, 1910-1955”, M.A. dissertation, University of Zimbabwe, 1987.

Machingaidze V.E.M, "The development of setter capitalist agriculture in Southern Rhodesia with particular reference to the role of the state, 1908-1939", Unpublished Doctoral thesis, University of London, 1980. 
Mugodzwa D, "Peasant production in Charter District, 1890-1923", Unpublished M.A. thesis, University of Zimbabwe, History Department, 1996.

Mtetwa R.M.G, "The 'political' history and economic history of the Duma people of southeastern Rhodesia from the early 18 century to 1945”, Unpublished D.Phil. thesis, 1976.

\section{Archival sources: Zimbabwe National Archives, Harare.}

Monthly Reports.

1. N9/4

2. N9/4/1-45. [Up to 1923].

Quarterly Reports.

1. N9/3.

2. N9/3/1-3. [Up to1900].

Half-yearly Reports.

1. N9/2.

2. N9/2/1-3. [Up to 1913].

Annual Reports.

1. N9/1.

2. N9/1/1-26 [Up to 1923]

Native Department Files [Charter.]

1. NSK Files

2. NSK1/1/1-3 [1898-1905].

Native Commissioner [Range Diary].

S716.

Native Commissioner's Court.

S614.

D. Oral Interviews in Charter District. [Informants were selected on the basis of age and residence.]

1. Chakabvepi Nyashanu, 88 years old, Chief Nyashanu area, 26-02-13.

2. Chakanetsa Redzo, 78 years old, Redzo area, peasant farmer, 24-02-13.

3. Chengeto Pfunye, 66 years old, Handikori Pfunye, peasant farmer, 26-02-13.

4. Chief Mutekedza, 88 years old, Mutekedza area, 21-02-13.

5. Chinoti Pfunye, 92 years old, headman's wife, Handikori village, 25-02-13.

6. Chipinda Gwatidzo, 84 years old, peasant farmer, Chawatama village, 21-2-13.

7. Kufahakurambwi Mutinhiri, 86 years old, peasant farmer, Chief Mutekedza area, 21-02-13.

8. Kushingaira Mutekedza, 62 years old, peasant farmer, Chief Mutekedza area, 21-02-13.

9. Machemera Muzari, 56 years old, peasant farmer, Handikori village, 19-02-13.

10. Makotore Pfunye, 66 years old, peasant farmer, Handikori village, 22-02-13.

11. Mujakari Mupfumira, 90 years old, peasant farmer, Handikori village, 26-02-13.

12. Muneni Mutonhiri, 67 years old, fisherman, Mwerahari area, 22-02-13.

13. Masarira Mutinhiri, 59 years old, Chief Mutekedza area, peasant farmer, 21-02-13.

14. Musarira Chawatama, 68 years old, Chawatama village, 18-02-13.

15. Mutambiranwa Mutinhiri, 92 years old, village headman, Chief Gambiza, 22-02-13.

16. Pamwe Choga, 77 years old, peasant farmer, Chief Mombeyarara area, 24-02-13.

17. Pengaudzoke Nyashanu, 72 years old, peasant farmer, Chief Nyashanu area, 26-02-13.

18. Pamunda Chaumba, 86 years old, peasant farmer, Save Area, 22-02-13.

19. Takaidza Gwatidzo, 55 years, peasant farmer, Tagarira village, 20-02-13.

20. Takaidza Munemo, 66 years, war veteran, Mutao Forest, 24-02-13.

21. Tapera Manduve, 78 years old, war veteran, Mutao Forest, 24-02-13. 
22. Tatenda Muzari, 59 years old, trader, Handikori village, 24-02-13.

23. Tichareva Muzari, 78 years, peasant farmer, Handikori village, 24-02-13.

24.Zemwe Pfunye, 84 years old, chief, Handikori area, 24-02-13. 